\title{
PLANY ZAWODOWE STUDENTÓW PEDAGOGIKI UNIWERSYTETU RZESZOWSKIEGO W KONTEKŚCIE MIEJSCA ICH ZAMIESZKANIA
}

\section{Abstract \\ Professional plans of students of pedagogy at the University of Rzeszów in the context of their place of residence}

Stable and permanent work is the fundament in the functioning of every person in the entire period of his adult life. Proper professional qualifications reinforce the area of employment, but their absence can contribute to the emergence of serious problems in finding a job. Career planning plays an important role in the period of school and university education. The article presents the results of surveys of students of pedagogical studies at the Faculty of Pedagogy of the University of Rzeszów on their professional plans, activities in the field of acquiring new qualifications and competencies, as well as perceiving the possibility of setting up a business or getting promotion during employment.

Keywords: education, work, qualifications, competence, experience, practice

\section{Streszczenie}

Stabilna i pewna praca stanowi fundament w zakresie działalności każdego człowieka w całym okresie jego dorosłego życia. Właściwe kwalifikacje zawodowe wzmacniają ten fundament, natomiast ich brak przyczynia się do powstania problemów ze znalezieniem odpowiedniej pracy. Planowanie kariery zawodowej odgrywa więc istotną rolę w okresie trwania edukacji szkolnej i uniwersyteckiej. W artykule przestawiono wyniki badań ankietowych studentów studiów pedagogicznych Wydziału Pedagogicznego Uniwersytetu Rzeszowskiego na temat ich planów zawodowych, aktywności w zakresie zdobywania nowych kwalifikacji, kompetencji, a także postrzegania możliwości założenia działalności gospodarczej bądź uzyskania awansu w trakcie zatrudnienia.

Słowa kluczowe: edukacja, praca, kwalifikacje, kompetencje, doświadczenie, praktyka 


\section{Wprowadzenie}

System edukacji składa się $\mathrm{z}$ wielu poziomów kształcenia. $\mathrm{Z}$ reguły kończą się one uzyskaniem kwalifikacji zawodowych niezbędnych w podjęciu pracy zawodowej. Głównym celem tego systemu jest umożliwienie jednostce właściwego przygotowania się zarówno teoretycznego, jak i praktycznego w zakresie prawidłowego wykonywania pracy. Nauczyciele, pedagodzy szkolni, doradcy zawodowi, psycholodzy odgrywają ważną rolę w procesie kształcenia. I tak na przykład doradcy podkreślają, że jednostka ma być przygotowana na częste zmiany w różnych dziedzinach życia spowodowanych głównie szybkim rozwojem technologii informacyjno-komunikacyjnych. Dlatego też między innymi wskazują oni na samorozwój i permanentną edukację, które należą do jednych z najważniejszych czynników determinujących warunki życia. Mogą być one podstawą dobrej jakości życia, a jej brak - przyczyną marginalizacji prowadzącej czasami nawet do wykluczenia. W dobie technologii informacyjno-komunikacyjnych i ich ciągłych zmian edukacja szkolna nie zapewnia sukcesu w społecznym i zawodowym funkcjonowaniu człowieka przez całe jego życie. Rozwój wiedzy i techniki we wszystkich dziedzinach jest zbyt szybki, by raz uzyskane kwalifikacje i kompetencje nie dezaktualizowały się przez kilkadziesiąt lat. Ciągła ich weryfikacja to już nie tyle warunek odnoszenia sukcesów zawodowych, ile sposób radzenia sobie z obowiązkami ról zawodowych i utrzymania się na rynku pracy [Chodkowski, 2012: 22-23]. Planowanie kariery wzmacnia między innymi proces przygotowania się do tych zmian, a nadto wpływa na większe zaangażowanie jednostki w zakresie zawodoznawstwa.

Sytuacja na rynku pracy znacząco utrudnia planowanie kariery zawodowej. Badani studenci zamieszkują obszar województwa podkarpackiego, które charakteryzuje się terenem górzystym, trudnym do zamieszkania i uprawy roli. Na podstawie raportów o sytuacji społeczno-gospodarczej województwa podkarpackiego za ostatnie lata 2015-2017 stwierdza się, że w tym obszarze występuje wciąż wysokie bezrobocie na poziomie $9 \%$ (średnia dla całego województwa), jakkolwiek w niektórych powiatach przekracza $17 \%$. W dodatku niższe zarobki mieszkańców w porównaniu z innymi województwami przekładają się na szereg niekorzystnych zjawisk prowadzących między innymi do zwiększenia ryzyka zagrożenia ubóstwem [BIP podkarpackie.pl, cop. 2013]. Generuje to wiele problemów związanych ze znalezieniem zatrudnienia zwłaszcza wśród absolwentów wyższych uczelni. Wielu z nich decyduje się na migrację do większych miast tworzących aglomerację, takich jak na przykład Kraków, Wrocław, Warszawa, Poznań, Gdańsk. Natomiast inni wyjeżdżają za granicę w celu znalezienia pracy.

Ryszard Domański zauważa, że wielkie aglomeracje, pełnią jednocześnie różne funkcje, między innymi gospodarcze, przemysłowe, handlowo-usługowe, transportowe, portowe, uniwersyteckie i inne. Ogólny rozwój miast wiąże się więc z lepszymi możliwościami zatrudnienia, bliskością edukacji, technologii, finansów, administracji, medycyny, rekreacji, a przede wszystkim organizacji gospodarki i kultury. Cała infrastruktura wielkomiejska przyciąga nie tylko nowych 
mieszkańców, ale też inwestorów, powstają również instytucje społeczne [Domański, 2005: 17-26].

Problemy województwa podkarpackiego związane między innymi z najmniejszym w kraju wskaźnikiem urbanizacji, z wysokim bezrobociem oraz niskimi zarobkami mieszkańców są dosyć istotne i mogą implikować pewne postrzeganie planowania kariery zawodowej przez studentów studiów pedagogicznych w kontekście ich miejsca zamieszkania.

\section{Planowanie kariery zawodowej}

Kariera zawodowa postrzegana jest przez różnych autorów poprzez jej subiektywne bądź obiektywne dymensje lub też z jednoczesnym uwzględnianiem obydwu wymiarów. To ostatnie stanowisko wyraża orientację holizmu poznawczego i zakłada postrzeganie pracownika jako człowieka w jego całożyciowym funkcjonowaniu, a organizacji jako kontekstu społecznego dla działań związanych z odgrywaniem roli zawodowej. Takie stanowisko na gruncie polskim upowszechnia Augustyn Bańka, który w karierze zawodowej wskazuje zarówno elementy subiektywne, dotyczące interpretacji podmiotu, jak i obiektywne, odzwierciedlające instytucjonalizację pracy w wymiarach organizacji i społeczeństwa. Do pierwszych autor zalicza aspiracje, oczekiwania, wartości, potrzeby, satysfakcję, a do obiektywnych - role i przypisane do nich pozycje, obowiązki wynikające z odgrywania ról oraz kompetencje, aktywności i decyzje niezbędne, by te obowiązki wypełniać [Bańka, 2006: 67].

Według Krystyny Lelińskiej kariera ma dwa znaczenia. W języku potocznym dotyczy zdobywania coraz wyższej pozycji zawodowej, ale może oznaczać też przebieg pracy zawodowej [Lelińska, 2006: 13-14]. Autorka za Alicją Kargulową definiuje karierę zawodową także jako listę wydarzeń składających się na życie, sekwencję zawodów i innych ról życiowych, które razem wyrażają stosunek danej osoby do pracy w aspekcie jej całkowitego procesu rozwoju osobowości [Lelińska, 2006: 14].

Agnieszka Cybal-Michalska wyjaśnia, że kariera ma procesualny charakter. Autorka wskazuje na proces, któremu podlega jednostka w obszarze doświadczania i praktykowania pracy zawodowej. Na podstawie znanych teorii rozwoju kariery (np. Delberta C. Millera, Douglasa T. Halla, Donalda E. Supera, Aleksego Pocztowskiego, Alicji Kargulowej i innych) wnioskuje za Susan Sears że:

[...] rozwój kariery rozpoczyna się wraz z początkiem życia i trwa nieprzerwanie do jego końca. Proces ten ma interdyscyplinarny charakter i jest sumą konstelacji psychologicznych, socjologicznych, edukacyjnych, fizycznych, socjologicznych, przyrodniczych, ekonomicznych i przypadkowych czynników, które łączą się, aby nadać kształt karierze jednostki w toku całego jej życia [Cybal-Michalska, 2013: 37]. 
John Arnold zaznacza, że „kariera obejmuje pojęcia statusu, awansu i wewnętrznej satysfakcji, podczas gdy praca oznacza coś, co człowiek robi, aby zarabiać na życie". Autor wskazuje powszechnie stosowaną definicję psychologów: Douglasa Halla i Barbary Lawrence, wedle której kariera to „ewolucyjna sekwencja eksperymentów zawodowych osoby trwających w czasie". John Arnold także zaznacza za Audrey Collin i Anthony G. Wattsem, że kariera jest rozwojem indywidualnym, w skład którego wchodzi: uczenie się i praca przez całe życie [Arnold, 2011: 1].

Murat Kayalar i Merit Özmutaf [2009: 240] tłumaczą pojęcie kariery za Yehudą Baruchem i Eliezer Rosenstein, jako „,proces rozwoju pracowników na ścieżce doświadczeń i miejsc pracy w organizacji”.

Niemniej ważnym aspektem kariery są możliwości jej właściwego planowania. Jak podaje Lelińska, kształtowanie umiejętności planowania kariery przez młodzież jest najważniejszym zadaniem wielu instytucji rynku pracy świadczących usługi w orientacji i poradnictwie zawodowym [Lelińska, 2006: 13].

Niektórzy autorzy, jak na przykład Ewa Krause (za Iwoną Korcz i Bogusławem Pietrulewiczem), dostrzega początek planowania kariery z chwilą wyboru przyszłego zawodu i odpowiedniej szkoły, gwarantującej zdobycie stosownego wykształcenia [Krause, 2012: 22].

Ewa Krause [2012: 23] wyjaśnia planowanie kariery - za Moniką Kosterą i Stanisławem Kownackim - jako „,proces, podczas którego konkretna osoba wytycza sobie cel lub cele profesjonalne, które zamierza osiągnąć, i wyznacza ścieżkę kariery". Autorka także cytuje definicję Iwony Korcz i Bogusława Pietrulewicza, stwierdzając, że planowanie to „proces obejmujący: analizę sytuacji wyjściowej danego człowieka, identyfikację jego preferencji karierowych, ustalenie zasadniczych celów kariery, a także określenie konkretnych sposobów i zasobu niezbędnych środków do ich realizacji” [Krause, 2012: 23].

Planowanie kariery jest $\mathrm{z}$ reguły złożonym procesem, składającym się z różnych etapów. I tak na przykład Krystyna Lelińska wyszczególnia następujące etapy: ustalanie celów, poszukiwanie rozwiązań i podejmowanie decyzji, które pozwolą systematycznie dążyć do obranych celów, a także wybór najodpowiedniejszej drogi między różnymi rozwiązaniami w celu osiągnięcia sukcesu w nieodległym terminie [Lelińska, 2006: 14].

Planowanie kariery jest związane $\mathrm{z}$ długoterminowym procesem wyznaczania różnych celów w zakresie wykonywanej pracy. W trakcie tego procesu człowiek zmierza do najlepszego przystosowania swojego organizmu w obszarze zatrudnienia. Stefan M. Kwiatkowski [1995: 219-220] stwierdza, że osiąganie pełnej adaptacji zależy od wielu uwarunkowań, obejmujących między innymi czynniki fizyczne (np. temperatura, oświetlenie, hałas itp.), techniczne wymogi pracy (w tym maszyny, narzędzia, organizacje pracy i normy technologiczne) oraz warunki społeczne (w tym relacje międzyludzkie, formalne i nieformalne, zależności, wartości i normy). Dosyć istotne oddziaływanie na wykonywanie pracy mają inne czynniki, takie jak: antropologia organizmu ludzkiego, inteligencja, uzdolnienia, erudycja, kwalifikacje, kompetencje, umiejętności, motywacja, postawy, aspiracje zawodowe, zaangażowanie, aktywność itp. 
Planowanie kariery wiąże się również bezpośrednio z określaniem przybliżonych terminów i sposobów realizacji założonych wcześniej celów. Pomocne są w tym rozmowy z doradcą zawodowym, oparte na umiejętnym i fachowym badaniu. Polegają one między innymi na przekazywaniu konkretnych wskazówek, informacji. $Z$ reguły doradca bada klienta i określa jego przydatność do zawodu [Wojtasik, 1993: 22-23].

Murat Kayalar i Merit Özmutaf [2009: 241] definiują planowanie kariery - za Samuelem Aryee i Yaw A. Debrah - jako ,proaktywny kurs kształtowania skutecznej kariery, na którą może wpływać poczucie kontroli”. Autorzy proponują także szersze wyjaśnienie planowania kariery, za Samuelem Aryee, Yaw A. Debrah i Douglasem Hallem, jako:

[...] celowy proces stania się świadomym siebie, szans, ograniczeń, wyborów i konsekwencji, gdzie występuje identyfikacja celów związanych z karierą, programowanie, edukacja i powiązane doświadczenia rozwojowe, aby zapewnić kierunek, czas i kolejność etapów, żeby osiągnąć określony cel kariery [Kayalar, Özmutaf, 2009: 241].

Eliza Antoniu wyjaśnia za Mielu Zlate planowanie kariery, które opiera się na „ocenie indywidualnych umiejętności, zainteresowań i motywacji, analizie możliwości organizacyjnych, wyznaczaniu celów kariery i opracowaniu strategii osiągnięcia tych celów”. Autorka wyszczególnia również pięć etapów indywidualnego planowania kariery i są to kolejno:

1) samoocena, która jest zbiorem informacji o sobie (np. o wartościach, zainteresowaniach, umiejętnościach), a także o ciągłej ocenie i raportowaniu innym;

2) odkrywanie potencjału, które polega na zbieraniu informacji o możliwościach istniejących wewnątrz organizacji, ale także poza nimi (m.in. szkolenia, samoedukacja i inne metody);

3) podejmowanie decyzji i ustalanie celów krótko i długoterminowych na potrzeby szkolenia, zmiany stanowiska, miejsca pracy/działu itp.;

4) planowanie, które polega na określeniu sposobów i środków osiągania celów (np. terminy, wymagania dotyczące zasobów itp.);

5) dążenie do osiągnięcia celów (realizacja poszczególnych etapów, decyzje o zachowaniu lub zmianie przebiegu kariery [Antoniu, 2010: 16]).

Ricky W. Griffin w planowaniu kariery koncentruje się zaś na jednostce, która dąży do osiągnięcia równowagi pomiędzy ogólną znajomością swoich zamiarów i pragnień. Właściwym podejściem do kariery jest realizacja planów zawodowych przez odpowiednio dobrane sposoby, by można było osiągnąc równowagę pomiędzy znajomością swoich zamiarów a nastawieniem się na konkretny cel, a także umiejętne dążenie do realizacji programu zgodnego z opracowanym wcześniej harmonogramem [Griffin, 1997: 763-764].

Inaczej podchodzi do kariery zawodowej James Stoner i współautorzy, ponieważ dostrzegają oni ważny aspekt planów krótko- i długoterminowych, które pomagają jednostce w podejmowaniu wielu ważnych decyzji. Sformułowany i zaplanowany cel z określonym terminem realizacji „staje” się normą efektywności, 
która pozwala na ocenę czynionych postępów. Cele pomagają jednostce w ocenie postępów, są więc istotnym elementem kontrolowania tego procesu. Ważną rolę odgrywa przy tym podejmowanie działań korygujących - modyfikujących jako konkretny plan działania, w momencie kiedy jednostka zauważy, że oddala się od obranego celu lub doświadcza dodatkowych, nieoczekiwanych przeszkód [Stoner i in., 2001: 263].

Adam Peszko również zauważa, że ,podejmowanie decyzji jest procesem, w trakcie którego decydent musi sam definiować, analizować, oceniać, podejmować ryzyko i prowadzić skuteczne działanie" [Peszko, 2002: 88].

W podsumowaniu różnych wyjaśnień na temat planowania kariery zawodowej, stwierdza się, że większość definicji koncentruje się między innymi na długoterminowym procesie wzrastania i rozwoju jednostki oraz podejmowania przez nią odpowiedzialnych i samodzielnych decyzji w zakresie realizacji aspiracji zawodowych. Ważną rolę odgrywają przy tym zarówno motywy jednostki, jak też jej systematyczne zaangażowanie $\mathrm{w}$ proces kształcenia.

Warto podkreślić, że człowiek w coraz większym stopniu wykorzystuje technologie informacyjno-komunikacyjne, a także nieustannie przystosowuje swój organizm do środowiska życia. $Z$ pewnością jednym z priorytetów tego procesu jest aktywność w edukacji przez systematyczne poszerzanie wiedzy, samoedukację, samorozwój, zdobywanie nowych kompetencji czy też kwalifikacji.

Celem dopełnienia różnych definicji należy jeszcze wymienić najważniejsze czynniki w planowaniu kariery zawodowej. Aneta Breś (jako doradca zawodowy) dokonuje podziału na czynniki wewnętrzne (związane bezpośrednio z człowiekiem) i zewnętrzne (znajdujące się poza człowiekiem). Autorka zalicza do czynników wewnętrznych: zainteresowania, uzdolnienia, umiejętności, zdolności, temperament, cechy charakteru, system wartości i stan zdrowia. Za czynniki zewnętrzne uznaje zaś: poznanie zawodów i ścieżek kształcenia, a także tendencji na rynku pracy [Breś, 2013].

Planowanie kariery jest monitorowane w wielu krajach na świecie. Prowadzi się badania zarówno absolwentów, jak i wychowanków w trakcie procesu kształcenia, a następnie analizuje i sporządza raporty w celu lepszego dostosowania ścieżki kształcenia do potrzeb rynku pracy [np. Alloway i in., 2004]. Publikowane są również wyniki badań z zakresu planowania kariery zawodowej [np. Kenny $\mathrm{i}$ in. (2006), Niles $\mathrm{i}$ in., (2011)]. Na polskim rynku widoczne są dwie pozycje empiryczne: Ewy Krause [2012], a także Agnieszki Cybal-Michalskiej [2013]. Coraz częstsze zmiany na rynku pracy wymuszają większą mobilność ze strony szkół, przygotowujących wychowanków do uzyskania właściwych kwalifikacji, a także ze strony specjalistów w zakresie monitorowania efektów kształcenia. 


\section{Metodologia badań własnych}

Przedmiotem mojego badania była analiza porównawcza planów zawodowych studentów Wydziału Pedagogicznego Uniwersytetu Rzeszowskiego studiujących na kierunku pedagogika w kontekście miejsca ich zamieszkania. Badani studenci studiowali na studiach pierwszego i drugiego stopnia w trybie stacjonarnym i niestacjonarnym. Niektórzy z nich wykonywali różne prace dorywcze zgodne $\mathrm{z}$ kierunkiem kształcenia lub inne.

Celem badania było wzbogacenie wiedzy w zakresie postrzegania przez studentów reprezentujących różne środowiska zamieszkania, możliwości ich zatrudnienia po uzyskaniu dyplomu ukończeniu studiów.

W nawiązaniu do tematu eksploracji sformułowano następujące problemy badawcze:

- Czy istnieją (a jeśli tak, to jakie) różnice w postrzeganiu planów zawodowych między studentami mieszkającymi na wsi i w mieście?

- Jakie są motywy wyboru studiów przez respondentów i czy znajdują się one w obszarze ich planów zawodowych?

- Czy studenci wyrażają gotowość do przekwalifikowania się w razie problemów w zatrudnieniu, a jeśli tak, to jakie dominują sposoby uzyskania nowych kwalifikacji?

- Czy studenci planują wyjazdy za granicę w celach zarobkowych i czy zamierzają założyć własną działalność gospodarczą?

Podstawą sformułowania odpowiedzi na powyższe pytania były wyniki badań przeprowadzonych w drugim półroczu 2015 roku i w pierwszym kwartale roku 2016 w populacji 251 studentów studiów pedagogicznych na Uniwersytecie Rzeszowskim metodą sondażu diagnostycznego, dzięki której uzyskano bezpośrednio informacje od badanych osób. Badanie zrealizowano techniką ankiety, a użytym do tego celu narzędziem był kwestionariusz ankiety. Wszystkie pytania ankietowe opracował autor artykułu. Studenci wypełniali ankiety bezpłatnie i anonimowo, a po ich weryfikacji odrzucono piętnaście z powodu niekompletnych odpowiedzi.

Dane z tabeli 1 wskazują, że spośród 236 badanych osób ponad 96\% stanowiły kobiety, co potwierdza tendencję podejmowania przez kobiety studiów pedagogicznych [Chodkowski, 2017: 88]. Jak stwierdza Agnieszka Gromkowska-Melosik [2015: 40], kobiety dominują również w zawodach nauczycielskich na wszystkich szczeblach edukacji. 
Tabela 1

Rozkład miejsca zamieszkania z podziałem na płeć badanych

\begin{tabular}{|l|c|c|c|c|}
\hline \multirow{3}{*}{ Pleć badanych } & $\begin{array}{c}\text { Wieś } \\
\mathbf{N = 1 6 6}\end{array}$ & $\mathbf{\%}$ & $\begin{array}{c}\text { Miasto } \\
\mathbf{N = 7 0} \\
\mathbf{B}\end{array}$ & $\mathbf{\%}$ \\
\hline Kobiety & 160 & 96,39 & 67 & 95,71 \\
\hline Mężczyźni & 6 & 3,61 & 3 & 4,29 \\
\hline
\end{tabular}

Źródło: badania własne.

Pedagogika należy do popularnych kierunków studiów, na które uczęszcza młodzież mieszkająca w obszarach wiejskich od wielu lat. Mimo trudności na rynku pracy i wysokiego wskaźnika bezrobocia, zwłaszcza na terenach wiejskich, placówki oświatowe są niejednokrotnie nielicznymi miejscami oferującymi pracę w bliskiej odległości od miejsca zamieszkania.

\section{Opracowanie badań własnych}

Proces edukacji w Polsce wynosi średnio około 17 lat. Na poziomie szkoły średniej jednostka podejmuje odpowiedzialną decyzję w zakresie dalszego kształcenia pod względem rozwoju osobistego i zawodowego. Kontynuacja kształcenia i zarazem wybór właściwej szkoły umożliwiają jednostce uzyskanie kwalifikacji zawodowych niezbędnych do podjęcia pracy. Wybór właściwych motywów zalicza się do ważnych czynników skutecznego działania jednostki. Dlatego zapytano studentów o motywy rozpoczęcia studiów pedagogicznych. Na podstawie wyników badań z tabeli 2 dotyczących motywów podjęcia studiów przez respondentów dominują trzy motywy: zainteresowania, rozwój osobisty i chęć pogłębienia wiedzy. Studenci zarówno z grupy A, jak i z grupy B otrzymali największe wartości w zakresie zainteresowań: $65,66 \%$ (A) i $67 \%$ (B). Kolejne miejsca zajęły motywy dotyczące rozwoju osobistego: $60,24 \%$ (A) i 55,71\% (B) oraz chęć pogłębienia wiedzy: prawie $39,76 \%$ (A) i 48,57\% (B). Można zauważyć, że te same motywy podjęcia studiów w grupie A i B otrzymały wartości procentowe na zbliżonym poziomie. Oznacza to poczucie odpowiedzialności młodych ludzi, którzy mają pewne oczekiwania i świadomie planują przyszłe zatrudnienie pod względem rozwoju zawodowego w zakresie kształcenia pedagogicznego [Byrne, Flood, 2005: 111-124]. 
Tabela 2

Motyw podjęcia studiów przez badanych studentów (do trzech wyborów)

\begin{tabular}{|l|r|r|r|r|}
\hline \multicolumn{1}{|c|}{ Motyw podjęcia studiów } & $\begin{array}{c}\text { Wieś } \\
\text { A }\end{array}$ & $\mathbf{\%}$ & $\begin{array}{c}\text { Miasto } \\
\text { B }\end{array}$ & \% \\
\hline Zainteresowania & 109 & 65,66 & 47 & 67,14 \\
\hline Uzdolnienia & 23 & 13,86 & 7 & 10,00 \\
\hline Chęć pogłębienia wiedzy & 66 & 39,76 & 34 & 48,57 \\
\hline Duże szanse na pracę & 26 & 15,66 & 11 & 15,71 \\
\hline Dobre zarobki & 7 & 4,22 & 3 & 4,29 \\
\hline Namowa rodziców & 11 & 6,63 & 6 & 8,57 \\
\hline Namowa przyjaciół & 14 & 8,43 & 8 & 11,43 \\
\hline Rozwój osobisty & 100 & 60,24 & 39 & 55,71 \\
\hline Rozwój społeczny & 23 & 13,86 & 6 & 8,57 \\
\hline Sieć kontaktów międzyludzkich & 26 & 15,66 & 8 & 11,43 \\
\hline Aby otrzymać dyplom & 61 & 36,75 & 31 & 44,29 \\
\hline $\begin{array}{l}\text { Nie dostałem się na inny } \\
\text { kierunek }\end{array}$ & 11 & 6,63 & 4 & 5,71 \\
\hline Inne & 4 & 2,41 & 9 & 12,86 \\
\hline
\end{tabular}

Źródło: badania własne.

Następne pytanie dotyczyło planów podjęcia pracy wśród badanych studentów zgodnie ze specjalnością studiów. Odpowiedzi respondentów potwierdzają główne motywy wyboru studiów na kierunku pedagogicznym. Dane z tabeli 3 wskazują, że powyżej 81\% młodzieży z obydwu grup studiuje pedagogikę ze względu na chęć podjęcia pracy w sektorze edukacji. Wynika stąd, że studenci wybrali kierunek i specjalizację z pełną odpowiedzialnością, pomimo dużych trudności w zatrudnieniu w instytucjach edukacyjnych oraz wielu dodatkowych obciążeń w trakcie wykonywania pracy nauczyciela.

Tabela 3

Plany podjęcia pracy zgodnie ze specjalnością studiów wśród badanych studentów

\begin{tabular}{|l|c|c|c|c|}
\hline $\begin{array}{c}\text { Chęć podjęcia pracy } \\
\text { zgodnie } \\
\text { z kwalifikacjami }\end{array}$ & $\begin{array}{c}\text { Wieś } \\
\text { N= 166 } \\
\text { A }\end{array}$ & $\mathbf{\%}$ & $\begin{array}{c}\text { Miasto } \\
\mathbf{N}=\mathbf{7 0} \\
\mathbf{B}\end{array}$ & $\mathbf{\%}$ \\
\hline Tak & 139 & 83,73 & 57 & 81,43 \\
\hline Nie & 9 & 5,42 & 8 & 11,43 \\
\hline $\begin{array}{l}\text { Nie zastanawiałem/am } \\
\text { się nad tym }\end{array}$ & 18 & 10,84 & 5 & 7,14 \\
\hline
\end{tabular}

Źródło: badania własne. 
Problemy ze znalezieniem etatu są efektem stagnacji na rynku pracy, zwłaszcza na terenach wiejskich. Nowe kwalifikacje mogą zwiększyć możliwości zatrudnienia. Dlatego też w następnym pytaniu zapytano respondentów o plany zawodowe związane ze zmianą kwalifikacji w razie trudności podjęcia pracy nauczyciela. Według danych $z$ tabeli 4 ponad $72 \%$ studentów z grupy A i B odpowiedziało twierdząco, że mają takie plany. Niecałe $9 \%$ respondentów z grupy A i B zakreśliło zaś opcję przeciwną (że nie mają takich planów). Studenci mieszkający na terenach wiejskich wyrazili większe zainteresowanie przekwalifikowaniem się. Być może jest to konsekwencja ich obserwacji dotyczącej utrzymującego się wysokiego wskaźnika bezrobocia, a także zwiększającego się deficytu etatów, zwłaszcza dla pedagogów.

Należy również zauważyć, że około 18\% respondentów z grupa A i 19\% respondentów z grupy B zakreśliło opcję neutralną, bez wskazania odpowiedzi „tak” lub „nie”. Może to oznaczać między innymi lekceważenie obecnej sytuacji zatrudnienia w sektorze edukacji lub brak planowania kariery zawodowej zgodnej z kierunkiem studiów.

Tabela 4

Plany dotyczące zmiany kwalifikacji badanych studentów w razie trudności ze znalezieniem pracy

\begin{tabular}{|l|c|c|c|c|}
\hline $\begin{array}{c}\text { Czy w razie trudności } \\
\text { ze znalezieniem pracy } \\
\text { planujesz zmianę } \\
\text { kwalifikacji? }\end{array}$ & $\begin{array}{c}\text { Wieś } \\
\mathbf{N = 1 6 6}\end{array}$ & $\mathbf{A}$ & $\begin{array}{c}\text { Miasto } \\
\mathbf{N = 7 0} \\
\mathbf{B}\end{array}$ & $\mathbf{\%}$ \\
\hline Zdecydowanie tak & 61 & 36,75 & 22 & 31,43 \\
\hline Raczej tak & 62 & 37,35 & 29 & 41,43 \\
\hline Trudno powiedzieć & 29 & 17,47 & 13 & 18,57 \\
\hline Raczej nie & 11 & 6,63 & 6 & 8,57 \\
\hline Zdecydowanie nie & 3 & 1,81 & 0 & 0,00 \\
\hline
\end{tabular}

Źródło: badania własne.

Zmiana kwalifikacji wiąże się z właściwym wyborem formalnego szkolenia, aby zgodnie z przepisami prawa i obowiązującą klasyfikacją zawodów otrzymać właściwy certyfikat, świadectwo czy inny dokument stwierdzający przygotowanie do wykonywania pracy $\mathrm{w}$ danym zawodzie.

Jedną z wielu możliwości zmiany kwalifikacji są studia podyplomowe, bardzo popularne wśród absolwentów studiów zarówno licencjackich, jak i magisterskich. Aleksandra Marcinkiewicz stwierdza, że „szkoły wyższe często nie są w stanie w pełni przygotować absolwentów do pracy zawodowej w obranych specjalnościach”. Autorka dodaje, że „ta forma kształcenia jest w stanie szybciej reagować na potrzeby rynku pracy niż studia I i II stopnia, co jest jej niezwykłym atutem". 
Dlatego też wiele osób decyduje się na rozszerzanie i uzupełnianie wykształcenia akademickiego, aby być bardziej mobilnym i atrakcyjnym na zmieniającym się rynku pracy [Marcinkiewicz, 2012: 55].

W następnym pytaniu zapytano respondentów o sposoby zmiany kwalifikacji $\mathrm{w}$ razie napotkanych trudności w realizacji planów zawodowych.

Według danych z tabeli 5 studenci z obszarów wiejskich planują w większości płatne studia podyplomowe: $46,39 \%$, w porównaniu z młodzieżą miejską, której motywy zmiany kwalifikacji w postaci podjęcia płatnych studiów podyplomowych wyniosły $31,43 \%$. Na podstawie wyników badań potwierdza się dążenie młodzieży akademickiej do zdobywania nowych kwalifikacji zawodowych opisanych przez Marcinkiewicz. W dodatku należy pamiętać, że różnorodność kwalifikacji daje większe możliwości znalezienia zatrudnienia, a także ,umacnia” jednostkę na stanowisku pracy w wielu sytuacjach. Dla przykładu nauczyciel języka polskiego posiadający specjalizację z logopedii może dodatkowo wspierać dzieci potrzebujące pomocy w zakresie na przykład wady wymowy.

Oprócz studiów podyplomowych niektórzy respondenci zakreślili także inne formy kształcenia, w tym: bezpłatne szkolenia z funduszy unijnych, a także kursy organizowane przez urzędy pracy.

Można ogólnie stwierdzić, że studenci są aktywni - próbują zarabiać poprzez podejmowanie i wykonywanie różnego rodzaju prac dorywczych. Niektórym udaje się uzyskać etat, chociaż nie zawsze jest on zgodny z kierunkiem studiów. Dostrzegają więc konieczność zdobywania nowych kwalifikacji w ramach różnych dostępnych dla nich form kształcenia.

Tabela 5

Sposoby zmiany kwalifikacji badanych studentów w razie trudności ze znalezieniem pracy

\begin{tabular}{|l|c|c|c|c|}
\hline \multicolumn{1}{|c|}{$\begin{array}{c}\text { Sposoby zmiany } \\
\text { kwalifikacji }\end{array}$} & $\begin{array}{c}\text { Wieś } \\
\text { N= 166 } \\
\mathbf{A}\end{array}$ & $\mathbf{\%}$ & $\begin{array}{c}\text { Miasto } \\
\mathbf{N = 7 0} \\
\mathbf{B}\end{array}$ & $\mathbf{\%}$ \\
\hline Studia podyplomowe (płatne) & 77 & 46,39 & 22 & 31,43 \\
\hline Inne płatne formy kształcenia & 26 & 15,66 & 16 & 22,86 \\
\hline $\begin{array}{l}\text { Bezpłatne szkolenia } \\
\text { z funduszy unijnych }\end{array}$ & 23 & 13,86 & 13 & 18,57 \\
\hline $\begin{array}{l}\text { Kursy organizowane przez } \\
\text { urząd pracy }\end{array}$ & 20 & 12,05 & 8 & 11,43 \\
\hline Inne & 20 & 12,05 & 11 & 15,71 \\
\hline
\end{tabular}

Źródło: badania własne.

Od kilku lat stale rośnie emigracja ekonomiczna młodych osób. Polacy wyjeżdżają do Wielkiej Brytanii, Niemiec, Włoch i wielu innych krajów, mając różne kwalifikacje, zarówno wysokie, jak i niskie. Badani studenci dokonywali podobnych wyborów. 
Na podstawie badań przeprowadzonych przez Work Service główną motywacją do wyjazdów są: możliwość podwyższenia zarobków, chęć podniesienia standardu życia lub brak odpowiedniej pracy w Polsce. Osoby wyjeżdżające częstokroć mogą liczyć na lepszą pomoc socjalną i wsparcie ze strony pracodawcy lub lokalnych władz. Za granicą przebywa więcej kobiet (51,1\%) niż mężczyzn (48,9\%); decyzję o emigracji częściej podejmują mieszkańcy miast. Ponad $60 \%$ osób w wieku od 18 do 24 lat jest zainteresowanych emigracją i podjęciem pracy za granicą [Emigracja..., 2015].

Według danych z tabeli 6 plany emigracyjne wśród studentów z grupy A i z grupy B były na podobnym poziomie - w granicach $65 \%$. Z kolei w przypadku braku planów wyjazdowych większe wartości procentowe (prawie 26\%) uzyskali studenci z grupy B. Stosunkowo więcej osób z grupy A planuje wyjechać z kraju i ma nadzieję na lepsze wynagrodzenie i związane $z$ tym plany zawodowe, a także rodzinne. W grupie B wyższe wartości procentowe dotyczyły zaś odpowiedzi przeciwnych emigracji ekonomicznej. Być może studenci mieszkający w miastach mają więcej możliwości na lokalnym rynku pracy, dlatego nie są zainteresowani wyjazdem z kraju i w większości przypadków koncentrują się na rynku krajowym.

Tabela 6

Plany wyjazdu za granicę celem podjęcia pracy zarobkowej przez badanych studentów

\begin{tabular}{|c|c|c|c|c|}
\hline $\begin{array}{c}\text { Czy planujesz } \\
\text { wyjazd za granicę } \\
\text { w celu podjęcia } \\
\text { pracy zarobkowej? }\end{array}$ & $\begin{array}{c}\text { Wieś } \\
\mathrm{N}=166 \\
\mathrm{~A}\end{array}$ & $\%$ & $\begin{array}{c}\text { Miasto } \\
\mathbf{N}=70 \\
\text { B }\end{array}$ & $\%$ \\
\hline Zdecydowanie tak & 64 & 38,55 & 24 & 34,29 \\
\hline Raczej tak & 43 & 25,90 & 19 & 27,14 \\
\hline Trudno powiedzieć & 38 & 22,89 & 9 & 12,86 \\
\hline Raczej nie & 13 & 7,83 & 11 & 15,71 \\
\hline Zdecydowanie nie & 8 & 4,82 & 7 & 10,00 \\
\hline
\end{tabular}

Źródło: badania własne.

Kolejne pytanie (tabela 7) dotyczyło planów założenia własnej działalności gospodarczej na wypadek niepowodzeń w znalezieniu pracy najemnej. Wyższe wartości procentowe otrzymano wśród ankietowanych z grupy B. Studenci z miast są zdecydowanie lepiej ustosunkowani do założenia i prowadzenia działalności gospodarczej w porównaniu z młodzieżą zamieszkałą na terenach wiejskich. 
Plany założenia własnej działalności gospodarczej według respondentów

\begin{tabular}{|l|c|c|c|c|}
\hline $\begin{array}{c}\text { Czy planujesz zalożyć } \\
\text { własną dzialalność } \\
\text { gospodarczą? }\end{array}$ & $\begin{array}{c}\text { Wieś } \\
\text { N= 166 } \\
\text { A }\end{array}$ & $\mathbf{\%}$ & $\begin{array}{c}\text { Miasto } \\
\mathbf{N = 7 0} \\
\text { B }\end{array}$ & \% \\
\hline Zdecydowanie tak & 16 & 9,64 & 9 & 12,86 \\
\hline Raczej tak & 43 & 25,90 & 27 & 38,57 \\
\hline Trudno powiedzieć & 64 & 38,55 & 17 & 24,29 \\
\hline Raczej nie & 33 & 19,88 & 14 & 20,00 \\
\hline Zdecydowanie nie & 10 & 6,02 & 3 & 4,29 \\
\hline
\end{tabular}

Źródło: badania własne.

Zmiana rodzaju pracy jest czasami niezbędna ze względu na uwarunkowania psychofizyczne pracownika. Zawód nauczyciela wiąże się bowiem z dużym ryzykiem wypalenia zawodowego. Oznacza to stan wyczerpania jednostki spowodowany nadmiernymi wymaganiami stawianymi jej przez środowisko pracy [Woźniak-Krakowian, 2013: 119]. W dodatku dostrzega się wiele czynników niekorzystnie wpływających na przyspieszenie tego syndromu. Do tych najważniejszych można zaliczyć: coraz większe wymagania ze strony przełożonych, a także rodziców, niski status społeczny nauczyciela, brak możliwości awansu, brak stabilności, niskie wynagrodzenie, częsta zmiana przepisów prawnych i wprowadzanie nowych programów kształcenia.

Tabela 8

Ocena możliwości prowadzenia działalności gospodarczej według respondentów

\begin{tabular}{|l|c|c|c|c|}
\hline $\begin{array}{c}\text { Ocena możliwości } \\
\text { prowadzenia dzialalności }\end{array}$ & $\begin{array}{c}\text { Wieś } \\
\mathbf{N = 1 6 6} \\
\mathbf{A}\end{array}$ & $\mathbf{\%}$ & $\begin{array}{c}\text { Miasto } \\
\mathbf{N = 7 0} \\
\mathbf{B}\end{array}$ & $\mathbf{\%}$ \\
\hline Duże & 21 & 12,65 & 14 & 20,00 \\
\hline Niewielkie & 16 & 9,64 & 6 & 8,57 \\
\hline Trudno powiedzieć & 81 & 48,80 & 36 & 51,43 \\
\hline Nie mam żadnych szans & 3 & 1,81 & 2 & 2,86 \\
\hline Nie jestem zainteresowany/a & 5 & 3,01 & 10 & 14,29 \\
\hline Inne & 40 & 24,10 & 2 & 2,86 \\
\hline
\end{tabular}

Źródło: badania własne. 
Ostatnie pytanie dotyczyło oceny możliwości prowadzenia działalności gospodarczej. Na podstawie danych z tabeli 8 respondenci z grupy B uzyskali zdecydowanie wyższą wartość wynoszącą 20\%, w porównaniu ze studentami z grupy A (12,65\%). Oznacza to, że zarówno plany założenia własnej działalności gospodarczej, jak i zamiar jej prowadzenia uzyskały wyższe wartości dla mieszkańców miast w porównaniu z respondentami ze środowisk wiejskich.

Zapotrzebowanie na opiekę sprawowaną nad ludźmi w różnym wieku nieustannie wzrasta. Powstają prywatne żłobki i przedszkola, a także domy spokojnej starości, które generują nowe miejsca pracy. Studenci są tego świadomi, dlatego w swoich planach zawodowych biorą pod uwagę także założenie i prowadzenie własnej działalności gospodarczej. Należy jednak zaznaczyć, że około $50 \%$ respondentów z obydwu grup nie wyraziło swojego zdania na temat prowadzenia działalności. Być może stanowi to odległą perspektywę w planowaniu kariery zawodowej bądź nie są oni w ogóle zainteresowani takim rodzajem pracy.

\section{Zakończenie}

Rynek pracy charakteryzuje się dużą nieprzewidywalnością i częstokroć niekorzystną koniunkturą w obszarze nowych etatów. Taki stan przyczynia się do pesymizmu i zniechęcenia, zwłaszcza wśród młodych absolwentów szkół. Studenci, którzy wykazują pozytywne postawy w planowaniu kariery, mają pewną przewagę [Stoeber, Mutinelli, Corr, 2016: 256-259].

Powstało wiele opracowań w zakresie planowania kariery zawodowej przez polskich studentów [Chodkowski, 2012; Krause, 2012; Cybal-Michalska, 2013]. I tak na przykład Ewa Krause [2012: 231-235] stwierdza, że badani studenci posiadają wyobrażenia na temat własnej przyszłości i planów odnośnie do życia osobistego i zawodowego. Ujawniają własne preferencje i orientacje dotyczące zawodu oraz pracy zawodowej. Widzą też możliwości stwarzane przez procesy integracyjne w wyjazdach zarobkowych. Dostrzegają również obawy związane $\mathrm{z}$ różnymi przeszkodami (m.in. bezrobociem, trudnościami w pogodzeniu pracy zawodowej i życia osobistego).

W badaniach zaprezentowanych w niniejszym artykule młodzież studencka podobnie postrzegała plany zawodowe. W odpowiedziach na pytania, czy istnieją (a jeśli tak, to jakie) różnice w planach zawodowych wśród studentów w kontekście ich miejsca zamieszkania, widać, że głównym motywem wyboru kierunku studiów u respondentów z obydwu grup były zainteresowania. Następnymi motywami kolejno były: rozwój osobisty i chęć pogłębienia wiedzy. Otrzymane wartości procentowe nieznacznie różniły się między badanymi grupami.

Optymistyczne jest to, że studenci z obydwu grup podjęli studia pedagogiczne ze względu na chęć zdobycia kwalifikacji pedagogicznych i wykonywania pracy w zawodzie nauczyciela (ponad 81\%), pomimo wielu czynników zniechęcających.

Studenci z terenów wiejskich byli bardziej zainteresowani zmianą kwalifikacji ze względu na możliwości zwiększenia atrakcyjności na lokalnym rynku pracy, 
na którym stopa bezrobocia rejestrowanego utrzymuje się na wysokim poziomie i jest jedną z najwyższych w kraju. Dla przykładu w sierpniu 2016 wynosiła $11,6 \%$, w porównaniu z całym krajem, w którym poziom bezrobocia wynosił 8,5\% [Wskaźniki..., 2016].

Podobnie było z odpowiedziami na pytanie dotyczące sposobu zmiany kwalifikacji. Respondenci mieszkający na wsi częściej deklarowali chęć zmiany kwalifikacji głównie poprzez studia podyplomowe, co potwierdza ich wysokie aspiracje zawodowe związane $\mathrm{z}$ uzyskaniem nowych umiejętności i poszerzeniem możliwości znalezienia pracy.

Emigracja ekonomiczna Polaków kształtuje się na poziomie około 2 mln osób. Dominują młodzi - osoby do 26 roku życia. Odpowiedzi studentów z obydwu grup potwierdziły tendencję wyjazdów zarobkowych. W tym badaniu nieznaczną przewagę liczbową osiągnęli studenci z terenów wiejskich.

Jednym z wielu sposobów pomocy absolwentom jest opracowanie specjalnych programów, dzięki którym dostrzegą oni możliwości zatrudnienia i realizacji swoich planów zawodowych, a także rodzinnych w miejscach zamieszkania - zwłaszcza w obszarach górzystych [Chodkowski, 2017: 91].

Trudności ze znalezieniem pracy dotykają w coraz większym stopniu absolwentów studiów pedagogicznych. Do głównych czynników wpływających na zmianę pracy zalicza się przede wszystkim: stresogenność, brak stabilizacji w zawodzie, niskie płace, rosnące wymagania i oczekiwania ze strony przełożonych, rodziców i dzieci, częste zmiany programów kształcenia i przepisów prawnych, coraz niższy status nauczyciela w społeczeństwie. Wszystkie wymienione czynniki przyczyniają się w krótkim czasie również do wypalenia zawodowego.

W podsumowaniu stwierdza się, że większość respondentów patrzy na swoje plany zawodowe przez pryzmat dużego bezrobocia, zwłaszcza na terenach wiejskich położonych w obszarach górzystych. Studenci widzą konieczność zdobycia nowych kwalifikacji, a także w dalszej perspektywie - możliwość założenia prywatnej działalności gospodarczej. Prawdopodobnie dla niektórych alternatywą będzie migracja wewnętrzna lub wyjazd ekonomiczny za granicę.

Zaleca się przeprowadzenie podobnych badań w celu zdiagnozowania postaw zawodowych młodzieży studenckiej w zakresie ich wyboru kierunku studiów i związanych z tym planów zawodowych. Wyniki badań mogą okazać się pomocne dla doradców zawodowych, szkolnych, a także w tworzeniu nowych programów kształcenia, które będą lepiej dostosowane do potrzeb zmieniającego się rynku pracy.

\section{Bibliografia}

Alloway N., Dalley L., Lenoy M., Patterson A., Walker K. (2004), School Students Making Education and Career Decisions: Aspirations, Attitudes and Influences. Final Report, School of Education, James Cook University, Canberra. 
Antoniu E. (2010), Career Planning Process and Its Role in Human, „, Resource Development Annals of the University of Petroşani, Economics", 10 (2).

Arnold J. (2011), Career Concepts in the 21 $1^{\text {st }}$ Century, „The Psychologist”, 24 (2).

Bańka A., (2006), Kapitat kariery - uwarunkowania, rozwój i adaptacja do zmian organizacyjnych oraz strukturalnych rynku pracy [w:] Z. Ratajczak, A. Bańka, E. Turska E. (red.), Współczesna psychologia pracy i organizacji, Wyd. Uniwersytetu Śląskiego, Katowice.

BIP podkarpackie (cop. 2013), http://www.bip.podkarpackie.pl [dostęp: 14.10.2018].

Breś A. ([2013]), Czynniki ważne przy planowaniu kariery zawodowej, https://www.metis.pl/ content/view/204/32 [dostęp: 14.10.2018].

Byrne M., Flood B. (2005), A Study of Accounting Students' Motives, Expectations and Preparedness for Higher Education, „Journal of Further and Higher Education”, 2 (29).

Chodkowski Z. (2012), Funkcjonowanie zawodowe słuchaczy pedagogicznych studiów podyplomowych, Wyd. Uniwersytetu Rzeszowskiego, Rzeszów.

Chodkowski Z. (2017), Możliwości i bariery funkcjonowania zawodowego młodzieży z wyższym wykształceniem w opiniach studentów, „Edukacja - Technika - Informatyka”, 1 (19).

Cybal-Michalska A. (2013), Młodzież akademicka a kariera zawodowa, Oficyna Wydawnicza Impuls, Kraków.

Domański R. (2005), Geografia ekonomiczna. Ujęcie dynamiczne, WN PWN, Warszawa.

Emigracja zarobkowa Polaków. Wyjeżḋa coraz więcej wykształconych (2015), http://www. money.pl/gospodarka/wiadomosci/artykul/emigracja-zarobkowa-polakow-wyjezdza-coraz,43,0,1864235.html [dostęp: 3.04.2016].

Griffin R.W. (1997), Podstawy zarzadzania organizacjami, tłum. M. Rusiński, WN PWN, Warszawa.

Gromkowska-Melosik A. (2015), Dostęp kobiet i mężczyzn do studiów wyższych. Studium porównawcze, „Rocznik Lubuski”, numer specjalny: „Polskie Szkolnictwo Wyższe - Stan i Perspektywy", 2 (41).

Kayalar M., Özmutaf M. (2009), The Effect of Individual Career Planning on Job Satisfaction: A Comparative Study on Academic and Administrative Staff, „The Journal of Faculty of Economics and Administrative Sciences", 1 (14).

Kenny M.E., Blustein D.L., Haase R.F., Jackson J., Perry J.C. (2006), Setting the Stage: Career Development and the Student Engagement Process, „Journal of Counseling Psychology", 53 (2).

Krause E. (2012), Planowanie rozwoju kariery zawodowej przez studentów: między wyobrażeniami a strategiami, Wyd. Uniwersytetu Kazimierza Wielkiego, Bydgoszcz.

Kwiatkowski S.M. (1995), Zakład pracy jako środowisko wychowawcze [w:] T. Pilch, I. Lepalczyk (red.), Pedagogika spoleczna, Wyd. Żak, Warszawa.

Lelińska K. (2006), Zawodoznawstwo w planowaniu kariery, Ochotnicze Hufce Pracy. Komenda Główna, Warszawa.

Marcinkiewicz A. (2012), Ksztatcenie podyplomowe wobec rynku pracy, „E-mentor”, 2 (44).

Peszko A. (2002), Podstawy zarządzania organizacjami, Wyd. AGH, Kraków.

Stoeber J., Mutinelli S., Corr P.J. (2016), Perfectionism in Students and Positive Career Planning Attitudes [w:] Personality and Individual Differences, „Elsevier”, 97, http://www.sciencedirect.com/science/article/pii/S0191886916302185 [dostęp: 16.04.2016].

Stoner J., Finch A., Freeman R.E., Gilbert D.R., Ehrlich A. (2001), Kierowanie, tłum. A. Ehrlich, Polskie Wydawnictwo Ekonomiczne, Warszawa. 
Wojtasik B. (1993), Doradca zawodu, Wyd. Uniwersytetu Wrocławskiego, Wrocław.

Woźniak-Krakowian A. (2013), Syndrom wypalenia zawodowego nauczycieli, „Prace Naukowe Akademii im. Jana Długosza w Częstochowie. Pedagogika", 22.

Wskaźniki rynku pracy. Aktualne wskaźniki dla Polski ([2016]), http://www.rynekpracy.pl/ wskazniki_woj.php?w=6\&podkarpackie [dostęp: 30.11.2016]. 